\title{
Does Public Procurement for Innovation Increase Innovative Efforts? The Case of Brazil ${ }^{1}$
}

\author{
Frederico Rocha ${ }^{2}$
}

(fred@ie.ufrj.br)

\begin{abstract}
The paper uses microdata from the Brazilian Innovation Survey (PINTEC) to assess the effect of public procurement of innovation (PPI) on firms' private R\&D expenditures. The PINTEC 2014 edition allows the identification of those firms that participated in PPI programs. Using this information, the paper builds a control sample through coarsened exact matching and tests the effect of PPI on firms private R\&D to sales ratio. The results show that firms increase their $R \& D$ intensity between 3 and 6 percentage points, depending on the controls used in the tobit model. Data also shows that most firms involved in PPI are small and belong to low technology sectors. These features unshed an important characteristic of PPI: its ability to target small firms and contribute to local development.
\end{abstract}

Keywords: public procurement of innovation; policy assessment; innovation policy; Brazil

\footnotetext{
${ }^{1}$ The author is grateful for financial support from CAF.

${ }^{2}$ Professor at the Instituto de Economia at the Universidade Federal do Rio de Janeiro.
} 


\section{INTRODUCTION}

In the wake of the shift of interest of policymakers and scholars towards demand side innovation forces, public procurement for innovation (PPI) has returned to the center of debates on innovation policy. This new wave has been illuminated by the systemic view of the innovative process. According to this view, innovation requires the use of complementary assets and knowledge that are held by different agents. Thus, innovation is an interactive process and policy should be able to handle this complexity. The emphasis of the literature relies on the need for a more systemic approach calling for policy measures and instruments that provide room for the promotion of interaction between agents. Demand is one important part of the innovative environment and, procurement specifically is one important instrument (Edquist, Vonortas and Zabala-Itarriagagoita 2015 Uyarra 2012, Edler and Georghiou 2007, Uyarra and Flanagan 2011, Block 2008, Mazzucatto 2011).

Literature has struggled over an adequate definition of PPI. The most diffused definition stresses the presence of demand for products that do not exist in the market (Edquist, Hommen and Tsipouri 2000), opposing off-the-shelf procurement. However, in between these two extremes there is a wide range of practices that may be useful to policymakers in the building of innovative environments and innovation networks (Edquist and ZabalaIturriagagoitia 2012, Uyarra and Flanagan 2011). Among these practices, driving procurement away from single lowest price targeting is one important measure (Uyarra 2012).

Historically, public procurement in Brazil has suffered from this limitation and privileged price targets over quality and innovative attributes. Not surprisingly, previous studies on the conduct and performance of public sector suppliers have found that firms that supply to the public sector display lower capabilities and performance when compared to other type of firms (Soares 2005 and Squeff 2014). In 2010, however, government passed a new legislation that permitted public sector procurement to pursue other goals rather than the lowest prices and allowed the practice of a preference margin of up to $25 \%$ to promote the development of technology through procurement. This was a big step towards a different agenda for public sector procurement. Previous experiences on PPI in Brazil, though restricted to strategic sectors, showed positive results (Ribeiro 2017, Rauen 2017 and Rocha 2017). However, no previous tests have been carried out analyzing the role played by the whole public sector's PPI after the publication of law 12349.

This paper aims at assessing the effect of the use of PPI as an innovation policy instrument on private R\&D expenditures of firms in the Brazilian Mining and Manufacturing industries. To carry out this task, the paper uses microdata from the Brazilian Innovation Survey (PINTEC). PINTEC inaugurated in its 2014 edition a question that deals with public intervention through PPI that may allow an adequate assessment of the potential of legislation changes.

This paper is organized in five sections including this introduction. The second section describes our analytical background, the definition and understanding of PPI used in the paper and the main empirical results of previous literature in the Brazilian case. The third section is dedicated to a description of the database, the firm population involved, and the assessment 
Encontro Nacional de

Economia Industrial e Inovação
Indústria e Desenvolvimento Econômico:

desafios e perspectivas

18 a 20 de setembro de 2018

Uberlândia - Minas Gerais

methods used. Section four presents the results of the regressions and discusses them in the context of the PPI literature. Section five drives the main conclusions from the paper.

\section{ANALYTICAL BACKGROUND}

There are two different approaches towards innovation policy depending on the vision one holds about the innovation process. According to the view one holds, different policy designs may be recommended. The first view is more directly based on a linear conception of the innovation policy and stresses the main characteristics of knowledge as a good to understand the main market imperfections that may arise when dealing with innovation. This view pays attention to externalities, that may bestow public good characteristics to innovative activities, and to asymmetric information and uncertainty that may determine under allocation of financial resources. Both characteristics deviate the allocation of resources from Pareto optimality. In these cases, market intervention may be a way to conduct the allocation back to Pareto optimality or to second-best situations. Property rights legislation and the correction of market prices are some of the prescribed policies. Resources may also be channeled through the financing of R\&D activities, the building of financial mechanisms and institutions such as venture capital funds, fiscal incentives, and the supply of non-reimbursable funds (Hall 2010, Arrow 1962).

The second view identifies government intervention as a road towards the building of knowledge networks. The network view emphasizes the systemic character of innovative activities and stresses the importance of structuring innovation networks. Innovation is not an isolated phenomenon and requires capabilities that may be accumulated by more than one actor. Thus, innovation should require the involvement of firms that hold complementary capabilities and the combination of these firms may face challenges that inhibit innovative efforts. Innovation policy should be used to overcome these obstacles.

There are important analytical consequences in the adoption of a network view of innovation: (i) one should deal with the complexity of the innovative process as supply-side characteristics are only a part of the problem; (ii)) the way actors of innovation networks interact matters, and this may differ across nations (Lundvall 1992), regions (Cassiolato, Lastres, and Maciel 2003), and sectors (Malerba and Nelson 2011); (iii) the institutional framework and infrastructure where the innovation system or network is embedded should affect innovative behavior; and (iv) the enhancement of innovative activity may involve the improvement of ongoing linkages or the establishment of not-yet-existent ones.

Thus, policy should primarily enable "learning-oriented interactions" and should be capable of fostering linkages between actors of the system or network (Edquist, Vonortas and ZubalaIturriagagoitia2015, Edler and Georghiou 2007). Demand side policies may promote such interactions or participate together with supply side policy instruments. Public procurement for innovation is one of the most popular types of demand side policies.

PPI should be distinguished from regular off-the-shelf governmental procurement. Edquist, Hommen, and Tsipouri $(2000,5)$ state that PPI "occurs when a public agency places an order for a product or system which does not exist at the time, but which could (probably) be developed within a reasonable period." It is a consensus that this definition may be too strict 
Encontro Nacional de

Economia Industrial e Inovação
Indústria e Desenvolvimento Econômico:

desafios e perspectivas

18 a 20 de setembro de 2018

Uberlândia - Minas Gerais

to cover all possible modes of PPI. Even Edquist, Hommen, and Tsipouri (2000) describe some public procurement functions that do not fit into this straight definition but may improve business activities. The presence of these types of functions may widen the range of roles PPI may play. Public procurement for innovation may involve activities that have innovative attributes. PPI may include the improvement of existing products or the capacitation of firms to produce domestically previously imported products. PPI should have innovative attributes to "target functions that satisfy human needs or solve societal problems" (Edquist and ZabalaIturriagagoitia 2012). These attributes may imply local innovative behavior though globally it may involve no novelty (adaptive vs developmental PPI). PPI may also include pre-commercial $R \& D$ and thus not include the creation of a specific product, but of new knowledge. Under these arguments, the definition of PPI must include: (i) those initiatives directly related to bringing about solutions not present in the market context before it takes place, (ii) the use of innovation-friendly practices that may promote new practices to public providers of goods and services, and (iii) the establishment of conditions conducive to firm capacitation and interactive learning.

There are advantages in using PPI. First, it provides a more interactive environment, in that there is exchange of information in the specification of products and needs or even in the joint development of these products (Mazzucatto 2013 and Block 2008). PPI may be a source of information on the demand for sophisticated goods (Edler and Giorghiou 2007) Second, it may be a source of reduction of uncertainty. Government may provide an important market and scale for newly developed products (Litchenberg 1987). Government may also be a guarantee of demand in the case of new products that are still inexistent in the market. PPI may provide the correct environment and reduce market uncertainty (Block 2008). In the case of high uncertainty, the procurement of pre-commercial R\&D may be a way to overcome technological uncertainty that arise from the market as was done in the ARPA project in the US (Block 2008).

PPI may be an explicit instrument or an implicit instrument of innovation policies (Uyarra and Flanagan 2010). Rothwell (1984) advocates a more explicit role of PPI, mostly directed to the development of local capabilities. His main point is that regional development policies have been largely unsuccessful due to their incapacity to develop local capabilities. Thus, Rothwell (1984) proposes the use of PPI, together with other innovation policy instruments, to develop innovative behavior in local small firms. His arguments rely largely on the US experience of the US National Bureau of Standards, that promoted a change in public procurement away from the purchasing of the "cheapest products that met minimal design standards" towards the specification of "performance needs rather than design standards and purchased products with the lowest life cycle costs" (Herbert and Hoar 1982, apud Rothwell 1984:323).

PPI may direct governmental purchasing power towards innovation: (i) creating an environment that is responsive to innovation, (ii) stimulating the diffusion of new techniques and products, (iii) being proactive in the creation of new products and processes, (iv) specifying new needs, or even (v) procuring R\&D itself, in the case of pre-commercial R\&D (Edler et al. 2013).

Some of these uses of PPI are particularly important in developing countries where there is high structural heterogeneity due to the uneven diffusion of technical progress across and 
Encontro Nacional de

Economia Industrial e Inovação
Indústria e Desenvolvimento Econômico:

desafios e perspectivas

18 a 20 de setembro de 2018

Uberlândia - Minas Gerais

inside sectors (Pinto 1970). The presence of a qualified client that requires up to date, quality products, demands innovation from suppliers and interacts with them aiming the capacitation of firms may be an important tool to overcome some of the obstacles to the diffusion of technical progress mostly when small firms are concerned. This concern coincides with Rothwell's approach to PPI towards the capacitation of small firms in regional development.

However, PPI may face important obstacles for its implementation. Public sector agencies, companies and agents may lack the necessary capabilities as a client to specify or jointly develop products. Risk averse public agents may also jeopardize the full potential of public procurement and public legislation may be disproportionately focused on price as the key variable (Uyarra 2012).

Brazil's governmental procurement since the promulgation of law 8666/1993 was mostly directed towards the acquisition of the "cheapest products that met minimal design standards". The country's first general step towards the strategic use of procurement for innovative policy purposes appeared in the Innovation Law, promulgated in 2004 (10973/2004). This latter law authorized governmental entities to procure R\&D services and to promote the development of technology through procurement (Rauen 2015). The first time PPI explicitly appeared as a governmental strategy was in the Policy for Productive Development launched in 2008. However only in 2010 the government passed a bill that changed the rules for federal procurement and made viable the hiring possibilities that were proposed in the Innovation Law, allowing the use of a preference margin of up to $25 \%$ for domestic firms over foreign suppliers' price (law 12349/2010) and most importantly ending a long period focusing on price rather than quality and innovative attributes (Sousa and Oliveira 2010)..$^{3}$

Law 12349/2010 was followed by the edition of federal decree 7546/2011, that established the conditions under which these could be used. This new legislation accepted the use of the preference margin to induce the improvement of suppliers' practices and products and the operation of procurement policy for innovative purposes. The legislation allowed restrictions of local content in the acquisition of communication and informatics equipment; it also permitted a waiver from the use of public auctions for the acquisition of equipment, whenever using resources originated in public innovation support agencies, and the use of alternative methods of procurement whenever exchange of knowledge across economic agents was involved. In the following years, a sequence of public decrees developed specific contract designs using this legislation attending different economic sector (Squeff 2014).

It is therefore no surprise that previous empirical work that have analyzed the effect of public procurement on innovation has not shown good results. Soares (2005) analyzes the characteristics of firms that supplied to Brazilian government from 2001 to 2003 . He shows that the higher the share of governmental acquisitions in firms' sales the lower its innovative behavior and efficiency according to various indicators. Squeff (2014) reproduces Soares (2005) method with a larger time horizon 2000 to 2010. She also finds a negative correlation between the share of governmental acquisitions in firms' sales and indicators related to

\footnotetext{
${ }^{3}$ Before that there were few initiatives in sectoral level mostly related to local content policy, as was the case of oil and gas (Rocha 2017).
} 
Encontro Nacional de

Economia Industrial e Inovação
Indústria e Desenvolvimento Econômico:

desafios e perspectivas

18 a 20 de setembro de 2018

Uberlândia - Minas Gerais

innovative behavior. The main conclusion from their work is that the most plausible effect of government procurement is to depress innovative capabilities. Squeff (2014) and Soares (2005) do not analyze PPI, but off-the-shelf procurement.

Analyses covering PPI experiences before law 12349 draw a more positive picture. Petrobras' ${ }^{4}$ procurement practices appear to have a positive effect on innovative behavior of its critical equipment suppliers, having a positive effect on the hiring of technical and scientific personnel. Furthermore, there was a tendency in this case for a larger effect on small firms, accompanying some of Rothwell's (1984) conclusions (Rocha 2017). The development of EMBRAER, a state-owned company until 1994, and a major commercial plane builder, is another of these experiences. The presence of Brazilian Department of Defense orders has helped EMBRAER to build new competences in the area before and after the privatization. The development of the AMX jet fighter was central for the development of the ERJ 145 and EMBRAER 170/190 families. Today, Brazilian Air Force is developing together with EMBRAER the KC 390 that will substitute for the Hercules carriers in military operations (Ribeiro 2017). The Sirius project that built a new particles accelerator in Brazil also showed a positive experience in developing suppliers' competences. This project involved the hiring of precommercial R\&D through subvention and afterwards the use of the results in obtaining national solutions for the supply of equipment (Rauen 2017).

However, little is known about the effect of law 12349/2010 on the innovative behavior and performance of firms. Part of this limitation is due to the difficulties in separating what is PPI from what is not. This paper will attempt to cover this shortcoming using new information available on the Brazilian Innovation Survey 2014 edition. The survey questioned firms about the use of public procurement programs to the development and market introduction of firms' innovative products. The paper holds the hypothesis that PPI has played a very important role in incentivizing firms to innovate and that this is central due to the size distribution of governmental suppliers.

\section{METHODOLOGY}

\subsection{THE DATABASE}

This paper uses data from the Brazilian Innovation Survey (PINTEC) for 2014. PINTEC is designed according to Oslo Manual principles. The survey uses stratified sampling to produce statistically significant samples of companies in the 10 to 29,30 to 99,100 to 249 and 250 to 499 employees' strata and full coverage for companies with 500 or more employees. The survey also builds statistically significant samples across two-digit sectors according to International Standard Industrial Classification (ISIC4). It also departs from the view that innovation is an exceptional event and thus attempts to cover all firms that have received or applied for governmental financial support and patents. Though the coverage of PINTEC also include utilities and services firms, this paper will cover only firms in manufacturing and mining industries. PINTEC 2014 interviewed a sample of 14 thousand manufacturing and mining companies, expandable to a total of 116 thousand firms of which 42 thousand were found to

\footnotetext{
${ }^{4}$ The Brazilian state-owned oil company.
} 
Encontro Nacional de

Economia Industrial e Inovação
Indústria e Desenvolvimento Econômico:

desafios e perspectivas

18 a 20 de setembro de 2018

Uberlândia - Minas Gerais

have introduced a new product or a new process to the firm from 2012 to 2014, and 17 thousand received public support for innovative efforts in the same period, most of which directed to special financial conditions for the acquisition of machinery.

PINTEC 2014 edition asked for the first time a question related to PPI. In previous versions of PINTEC, PPI was supposed to be included in "other" instruments. This is thus the first time PINTEC offers the opportunity to check the role played by PPI. The question described in the questionnaire does not however mention the specific law into which the instrument should be framed (in this case law 12349) as it does when dealing with fiscal mechanisms, for instance. This is one important shortcoming in the methodology for it does not allow the discrimination of the use of the law and leaves the definition of PPI solely to the perception of the firm representative.

In the expanded sample, PINTEC finds that 604 manufacturing and mining firms had benefited from PPI programs. This is a small part of total Brazilian governmental goods and services purchases. Squeff (2014) finds almost 20 thousand manufacturing firms participating in general governmental procurement of which 2.4 thousand were listed in the Industrial Annual Survey. ${ }^{5}$ The large difference between the number of firms participating in general procurement and firms that responded "yes" to the question about PPI suggests that firms were able to distinguish the two types of programs.

The distribution of firms in PPI per size is presented in Figure 1. PPI has the most favorable distribution towards small firms of all the policy instruments listed by PINTEC. Less than $10 \%$ of firms participating in PPI have 100 or more employees. The sectoral distribution of firms in the program is shown in Figure 2. The most frequent sector to use PPI is Rubber and Plastics, followed by food, wearing apparel and machinery. The sectoral distribution is important because it shows that most firms do not belong to high technology sectors, though the large majority of them have declared themselves as innovative.

The paper will not use expanded sample statistics and thus it will only rely on information provided by actual questionnaire respondents. As sampling strategy of PINTEC guarantees full coverage for firms over 500 employees, the sample is biased towards larger firms. Furthermore, it was necessary to work with data for sales and wages and PINTEC does not collect them, rather it uses information from the Industrial Annual Survey. The Industrial Annual Survey (PIA) interviews all firms with 30 or more employees and has a sample of firms between 5 and 29 employees. Thus, firms between 10 and 29 employees selected in the PINTEC sample are not necessarily will covered by PIA. We have chosen to use only original information from PIA and thus our sample has been reduced from 14 thousand to 10 thousand firms. The loss of coverage was almost totally located in firms between 5 and 29 employees.

Table 1 shows PINTEC questionnaire respondents according to firm size and the receipt of treatment by PPI. In total, 69 respondents declared to have been part of PPI programs and 65 out of these 69 declared to have introduced a process or product innovation. Firms that

\footnotetext{
5 The Annual Industrial Survey (PIA) covers all manufacturing and mining firms with 30 or more employees and a representative sample of firms with between 5 and 29 employees, resulting in a total of 48 thousand respondents.
} 


\section{ENEI}

Encontro Nacional de

Economia Industrial e Inovação
Indústria e Desenvolvimento Econômico:

desafios e perspectivas

18 a 20 de setembro de 2018

Uberlândia - Minas Gerais

participated in PPI programs were, on average, larger in size and paid higher wage than other PINTEC questionnaire respondents (see Table 2). Table 2 also shows two statistics for R\&D intensity. The first is the ratio of the full firms' R\&D expenditures to sales. The second refers to R\&D expenditures net of governmental support. PINTEC allows information on what percentage of a firm's R\&D expenditure have been funded by their own resources and what percentage comes from government or governmental agencies. The statistics in the last column of Table 2 refer only to the amounts that come from firms' own funds.

One important characteristic of PPI targeted firms is that they use other innovation policy instruments (Figure 3). A first consequence of this characteristic is that one should account for the effects of these instruments over firm conduct and performance (Guerzoni and Raitieri 2016). A second consequence is that these firms may be characterized as more aggressive actors in the innovative setting, eager to participate in governmental policies. 
Figure 1. Firms that participated in PPI, per size strata, Brazil, 2012-2014

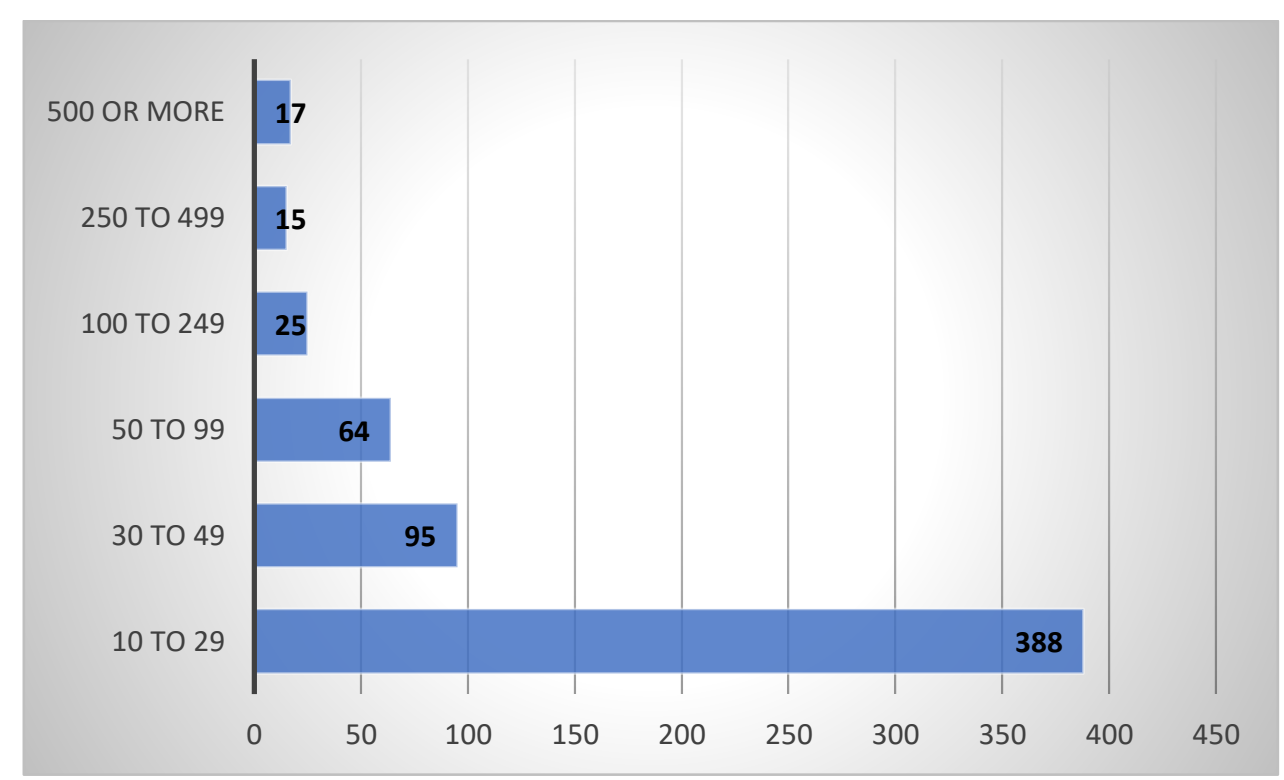

Source: IBGE, PINTEC (2014). 
Figure 2. Firms that participated in PPI, per sector, Brazil, 2012-2014

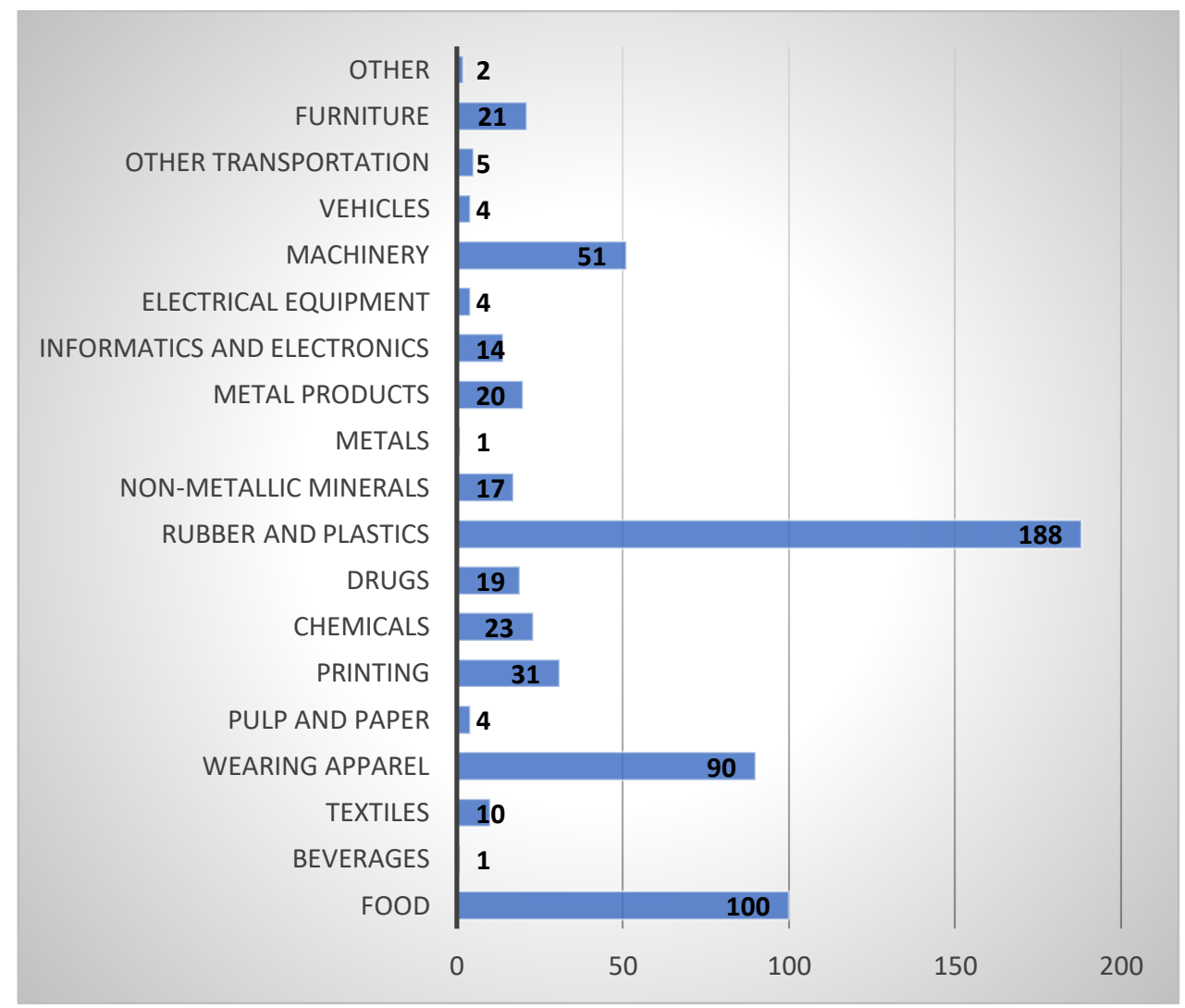

Source: IBGE, PINTEC (2014).

Table 1. Distribution of PINTEC questionnaire respondents by firm size strata, treated and non-treated with PPI, 2014

\begin{tabular}{lccc}
\hline & Non-PPI & PPI & Total \\
\hline 10 to 29 & 283 & 3 & 286 \\
30 to 99 & 3522 & 27 & 3549 \\
100 to 249 & 2835 & 16 & 2851 \\
250 to 499 & 1636 & 8 & 1644 \\
500 to 999 & 903 & 4 & 907 \\
1000 or more & 792 & 11 & 803 \\
\hline Total & 9971 & 69 & 10040 \\
\hline
\end{tabular}

Source: Own elaboration using microdata from PINTEC (2014). 
Figure 3. Firms in PPI Programs that used other innovation policy instruments, per instrument, 2012-2014

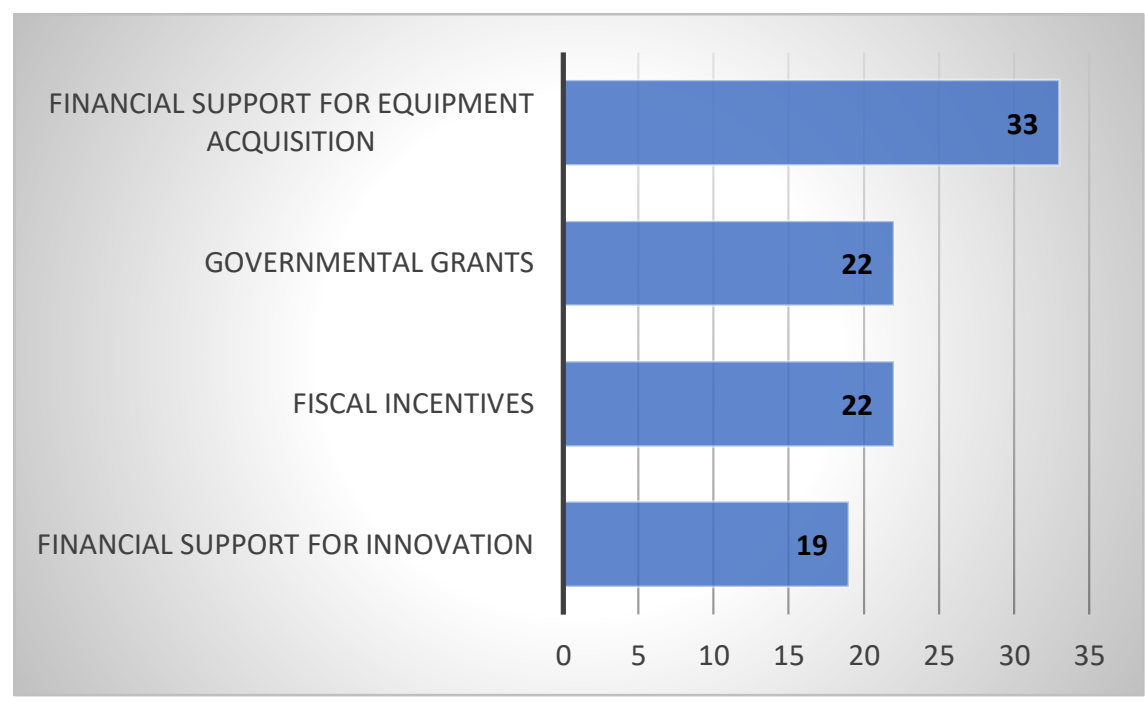

Source: Own elaboration using microdata from PINTEC (2014).

Table 2. Descriptive statistics of non-PPI and PPI participants, questionnaire respondents, 2012-2014

\begin{tabular}{llccccc}
\hline \multirow{2}{*}{ Tabl } & & $\begin{array}{c}\text { Number of } \\
\text { Employees }\end{array}$ & $\begin{array}{c}\text { Number of } \\
\text { Innovative Firms }\end{array}$ & $\begin{array}{c}\text { Average } \\
\text { wage }\end{array}$ & $\begin{array}{c}\text { R\&D/sales } \\
\text { Non-PPI }\end{array}$ & $\begin{array}{c}\text { Private } \\
\text { R\&Dales }\end{array}$ \\
& Count & 9971 & 9971 & 9965 & 9971 & 9971 \\
& Mean & 452 & 0.527129 & 44 & 0.004633 & 0.004077 \\
& SD & 183 & 0.499289 & 36 & 0.023315 & 0.020995 \\
\hline PPI & Count & 69 & 69 & 69 & 69 & 69 \\
& Mean & 516 & 0.942029 & 54 & 0.023257 & 0.020524 \\
& SD & 106 & 0.235401 & 51 & 0.053347 & 0.051928 \\
\hline Total & Count & 10040 & 10040 & 10034 & 10040 & 10040 \\
& Mean & 452 & 0.52998 & 45 & 0.004761 & 0.00419 \\
& SD & 182 & 0.499125 & 36 & 0.023696 & 0.021398 \\
\hline
\end{tabular}

Source: Own elaboration using microdata from PINTEC (2014)

\subsection{Selection Biases}

One of the main obstacles to policy assessment is the presence of selection biases. They have two origins. On the one hand, risk averse governmental officials may choose the best firms to guarantee positive results for their intervention attempts and thus a positive correlation between behavior or performance and policy may be a consequence of choosing the better firms and not of having a good instrument. One the other hand, firms that already have innovative attributes may be more likely to present themselves to absorb the benefits of that policy. However, there may be no net result. 
Encontro Nacional de

Economia Industrial e Inovação
Indústria e Desenvolvimento Econômico:

desafios e perspectivas

18 a 20 de setembro de 2018

Uberlândia - Minas Gerais

Most recent studies use a quasi-experimental method, trying to compose a control sample with similar initial characteristics to the treated sample through matching. The aim of matching exercises is to equate the distribution of chosen characteristics (covariates) of the treated and control samples. The ideal matching would find identical twins for each treated subject.

The use of matching requires the adequate design of the exercise, highlighting the main exogenous firm characteristics that may affect the outcome, and only after dealing with these characteristics through the balancing of samples, analyze the outcome (Stuart 2010). The approach to the design of the experiment should involve an adequate analysis of firms' characteristics not affected by the treatment that may influence the outcome. The covariates should not be affected by the treatment and should include all firm's characteristics that may affect outcomes. This analysis has two important constraint: the available information on characteristics that may affect the outcome and the size of the population from which to draw the control sample. These constraints impose trade-offs and may influence the matching exercise one chooses.

Stuart (2010) lists four distance measures to build the matching exercise: (i) exact matching, (ii) Mahalanobis, (iii) propensity score, and (iv) linear propensity score. If the objective is to find the exact twins of treated objects, exact matching should be the preferable method. However, there are two important limitations. The use of covariates that may have too many values reduces the number of observation, due to the high requirement to exactly match the specific characteristic. The same observation limitation occurs when including too many covariates. Both problems are very costly in terms of loss of observations and may face larger limitations when dealing with small samples. Most papers on innovation policy choose to use propensity score matching (PSM). King and Nielsen (2016) argue however that the use of PSM may, contrary to its main objective, increase imbalance and inefficiency, due to its attempts to approximate a completely randomized experiment, rather than blocking a randomized experiment. One way to overcome these limitations is the use of coarsened exact matching that allows the use of categories instead of working with exact values (lacus, King, \& Porro, 2012). In this case, the main challenge is to adequately choose the distribution of observations in homogeneous categories.

The variables and their categories to build the control sample are shown in Table 3 . We have chosen to control by size according to IBGE's strata, splitting the upper stratum into two. One from 500 to 999 employees and the other for firms with 1000 or more employees. We decided to include a variable to control for employees' capabilities. PINTEC does not hold information on level of education, neither does PIA. Thus, we chose average wage as a proxy for employees' capabilities and we have split the sample into four basic strata. We also control for differences in technological opportunity and appropriability, including sectoral variables as put in Table 3. Finally, as presented in Figure 3, some firms that participate in PPI also are treated by other policies. We found important to control for the effects of other policies on innovative effort and included these variables into the matching exercise (Guerzoni and Raitieri 2015, Uyarra 2012). We purposely have not included other innovative characteristics as control variables, because they may be influenced by PPI as well innovative effort. 
Table 3. Variables and strata used in the Coarsened Exact Matching

\begin{tabular}{lc}
\hline Variable & Strata \\
\hline Size (number of employees) & 10 to 29 \\
30 to 99 & 100 to 249 \\
& 250 to 499 \\
& 500 to 999 \\
& 1000 or more \\
\hline Average wage & inferior $25 \%$ \\
& $25 \%$ to $50 \%$ \\
& $50 \%$ to $75 \%$ \\
Sector (ISIC3) & upper $25 \%$ \\
& $15-19$ \\
& $20-22$ \\
& $23-25$ \\
& 26 \\
\hline Firms that received fiscal benefits & $27-29$ \\
& $30-33$ \\
& $34-35$ \\
& 36 \\
\hline Firms that received financial support & 1 - if yes \\
& $0-$ otherwise \\
\hline & 1 - if yes \\
& $0-$ otherwise \\
\hline & $1-$ if yes \\
& $0-$ otherwise \\
\hline &
\end{tabular}

\subsection{THE MODEL}

Figure 4 shows the intervention logic of innovation policy. First, one applies the instrument, then a change in the conduct is expected. After, changes in performance with different time ranges may occur. In this paper, we are interested in understanding the influence PPI has on innovative effort. This option derives from the limited time frame available (only one PINTEC). ${ }^{6}$ We have chosen the ratio of private R\&D expenditures to sales as the effort variable to be evaluated. This variable is bounded on the lower side at zero and on the upper side at one, that is, it may assume a value of zero with positive probability and is a continuous variable up

\footnotetext{
${ }^{6}$ As has been said above, PINTEC 2014 is the only edition to as about PPI. The next PINTEC will be carried out from information for 2017 collected in 2018 and made available in the end of 2019. When we had access to PINTEC microdata PIA 2015 was not still available.
} 
Encontro Nacional de

Economia Industrial e Inovação
Indústria e Desenvolvimento Econômico:

desafios e perspectivas

18 a 20 de setembro de 2018

Uberlândia - Minas Gerais

to one, resulting on corner outcomes in both cases. ${ }^{7}$ To deal with this feature we applied a tobit instead of an OLS model. Thus, we estimated:

$$
\begin{aligned}
& \frac{\text { private } R \& D}{\text { sales }} i=\mathbf{x}_{\mathbf{i}} \boldsymbol{\beta}+u_{i} \mid \mathbf{x}_{\mathbf{i}} \sim \operatorname{Normal}(0, \sigma) \\
& \frac{\text { private } R \& D}{\text { sales }} i=\max \left(0, \frac{\text { private } R \& D}{\text { sales }} i\right)
\end{aligned}
$$

where $\frac{\text { private } R \& D}{\text { sales }} i$ is a latent variable that linearly depends on a vector of firm and sector characteristics, $\mathbf{x}_{\mathbf{i}}$, which is supposed to be normally distributed and $\frac{\text { private } R \& D}{\text { sales }} i$ is the observable dependent variable.

Figure 4. Intervention Logic

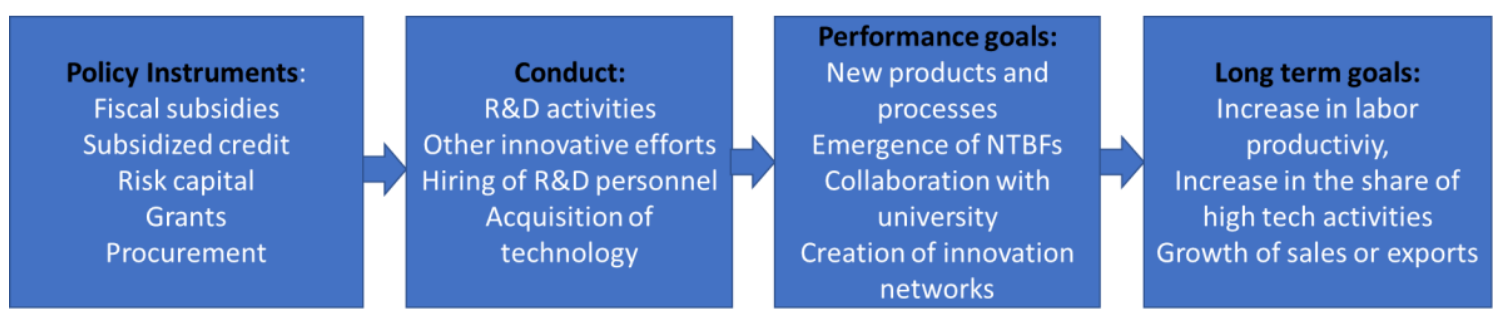

Source: Adaptation from Cunningham, Gök and Laredo (2013).

The independent variables are firm size, measured by the natural logarithm of the number of employees, average wage and a set of policy variables that should control for the use of other policies. To test the effect of policy designs on the outcome, we have decided to include variables for each policy instrument and interaction variables with procurement.

\section{RESULTS AND DISCUSSION}

Table 4 presents the results for the tobit regressions. Equations (1) and (2) differ with respect to the introduction of a quadratic form for the size variable (Insize2). Equation (3) includes variables representing other policy instruments used by firms and interaction variables between PPI and these instruments. Equation (4) reproduces equation (3) with the addition of the quadratic form variable for size.

In equations (1) and (2), PPI has a positive and significant at the $5 \%$ level sign, suggesting a positive effect of PPI on private R\&D intensity of little more than 3 percentage points. This is more than one standard deviation of the whole sample (see Table 2). The size variable (Insize) in equation (1) assumes a positive sign, significant at the $5 \%$ level. When one includes the quadratic form for size in equation (2), Insize reduces its value but increases its significance. The quadratic form assumes a negative and significant sign, suggesting a concave function. Its maximum value occurs when firms are larger than 100 thousand employees and no firm in manufacturing and mining has this size. Average wage has a positive sign that is significant at the $10 \%$ level in both equation (1) and (2).

\footnotetext{
${ }^{7}$ We have excluded all observations with R\&D intensity over 1.
} 


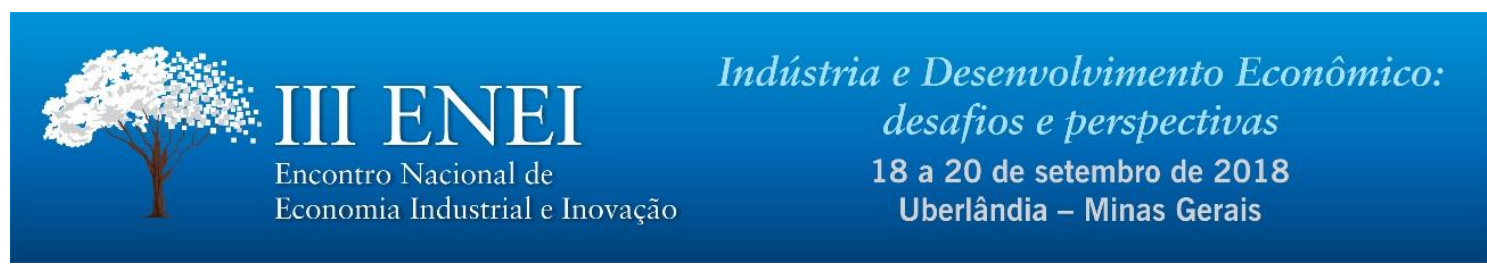

When we introduce variables representing other policy instruments, PPI becomes more significant ( $1 \%$ level) and increases its impact on private R\&D intensity to almost 6 percentage points, that is, more than twice the standard deviation of the whole sample of firms. This probably occurs due to higher R\&D disbursements in firms that are treated by other instruments more focused on R\&D activities. Thus, once we account for this bias, the impact on R\&D intensity increases. Nonetheless, the only other policy variable that maintains a positive and significant value is credit for innovative activities. ${ }^{8}$ The size variable in equation (3) remains positive but loses significance to the $10 \%$ level. In equation (4) the size variables have the same sign and similar values to equation (2).

Table 4. Tobit regressions

\begin{tabular}{|c|c|c|c|c|}
\hline & $(1)$ & $(2)$ & (3) & $(4)$ \\
\hline \multirow[t]{2}{*}{ PPI } & $0.0338^{* *}$ & $0.0305^{* *}$ & $0.0599 * * *$ & $0.0595 * * *$ \\
\hline & $(0.0147)$ & $(0.0146)$ & $(0.0214)$ & $(0.0213)$ \\
\hline \multirow[t]{2}{*}{ Insize } & $0.0160 * *$ & $0.108^{* * *}$ & $0.0123 *$ & $0.107^{* * *}$ \\
\hline & $(0.00615)$ & $(0.0397)$ & (0.00675) & $(0.0396)$ \\
\hline \multirow[t]{2}{*}{ Insize2 } & & $-0.00760 * *$ & & $-0.00786 * *$ \\
\hline & & $(0.00321)$ & & $(0.00318)$ \\
\hline \multirow[t]{2}{*}{ Average wage } & $0.000372 *$ & $0.000378 *$ & 0.000139 & 0.000143 \\
\hline & $(0.000215)$ & $(0.000210)$ & $(0.000221)$ & $(0.000216)$ \\
\hline \multirow[t]{2}{*}{ financial } & & & $0.0466^{*}$ & $0.0448 *$ \\
\hline & & & $(0.0265)$ & $(0.0260)$ \\
\hline \multirow[t]{2}{*}{ fiscal } & & & 0.0351 & 0.0410 \\
\hline & & & $(0.0305)$ & (0.0299) \\
\hline \multirow[t]{2}{*}{ grants } & & & 0.0138 & 0.0115 \\
\hline & & & (0.0269) & $(0.0265)$ \\
\hline \multirow[t]{2}{*}{ PPI*financial } & & & -0.0344 & -0.0326 \\
\hline & & & $(0.0352)$ & $(0.0344)$ \\
\hline \multirow[t]{2}{*}{ PPI*fiscal } & & & -0.00874 & -0.0213 \\
\hline & & & $(0.0381)$ & $(0.0377)$ \\
\hline \multirow[t]{2}{*}{$\mathrm{PPI}^{*}$ grants } & & & -0.0207 & -0.0151 \\
\hline & & & $(0.0361)$ & $(0.0356)$ \\
\hline \multirow[t]{2}{*}{ Constant } & $-0.147 * * *$ & $-0.404 * * *$ & $-0.151 * * *$ & $-0.420 * * *$ \\
\hline & $(0.0343)$ & $(0.118)$ & $(0.0382)$ & $(0.120)$ \\
\hline \multirow[t]{2}{*}{ sigma } & $0.0692 * * *$ & $0.0677 * * *$ & $0.0670 * * *$ & $0.0653^{* * *}$ \\
\hline & $(0.00689)$ & $(0.00671)$ & $(0.00663)$ & $(0.00643)$ \\
\hline Observations & 132 & 132 & 132 & 132 \\
\hline chi2 & 26.48 & 32.33 & 38.95 & 45.32 \\
\hline
\end{tabular}

8 Though only financial resources for innovative activities is the only significant variable for other policies, this does not mean that any of these policies are by anyway ineffective. The inclusion of these policy instruments in the regression have the only purpose to control for the effect of these instruments on R\&D. 


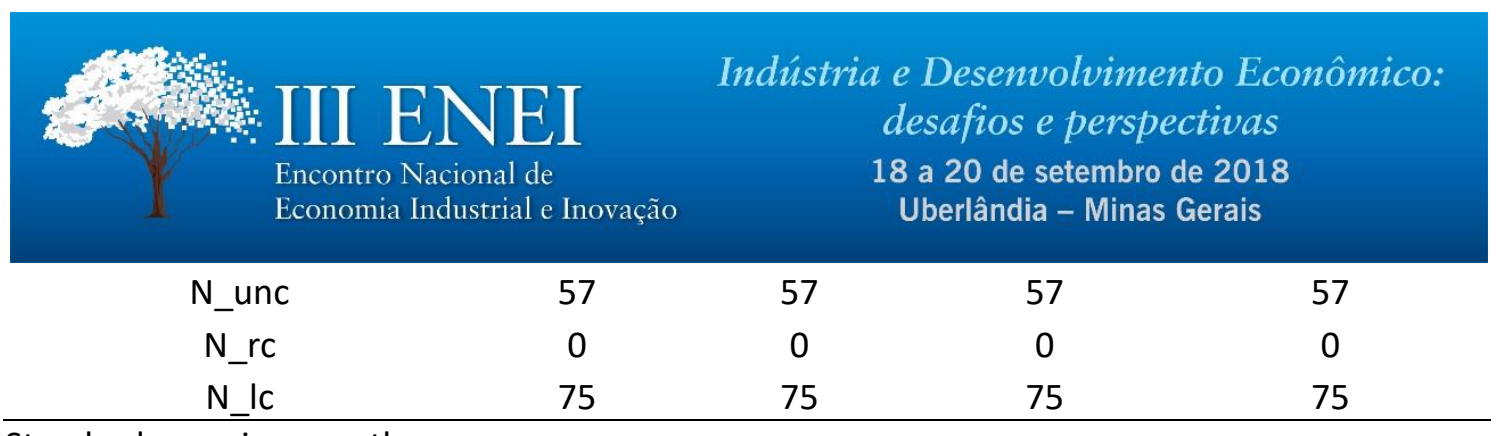

Standard error in parentheses.

${ }^{* * *} p<0.01,{ }^{* *} p<0.05,{ }^{*} p<0.1$. 
Figure 5. Distribution of Firms that Received Governmental Support per Instrument and Firm Size, 2012-2014

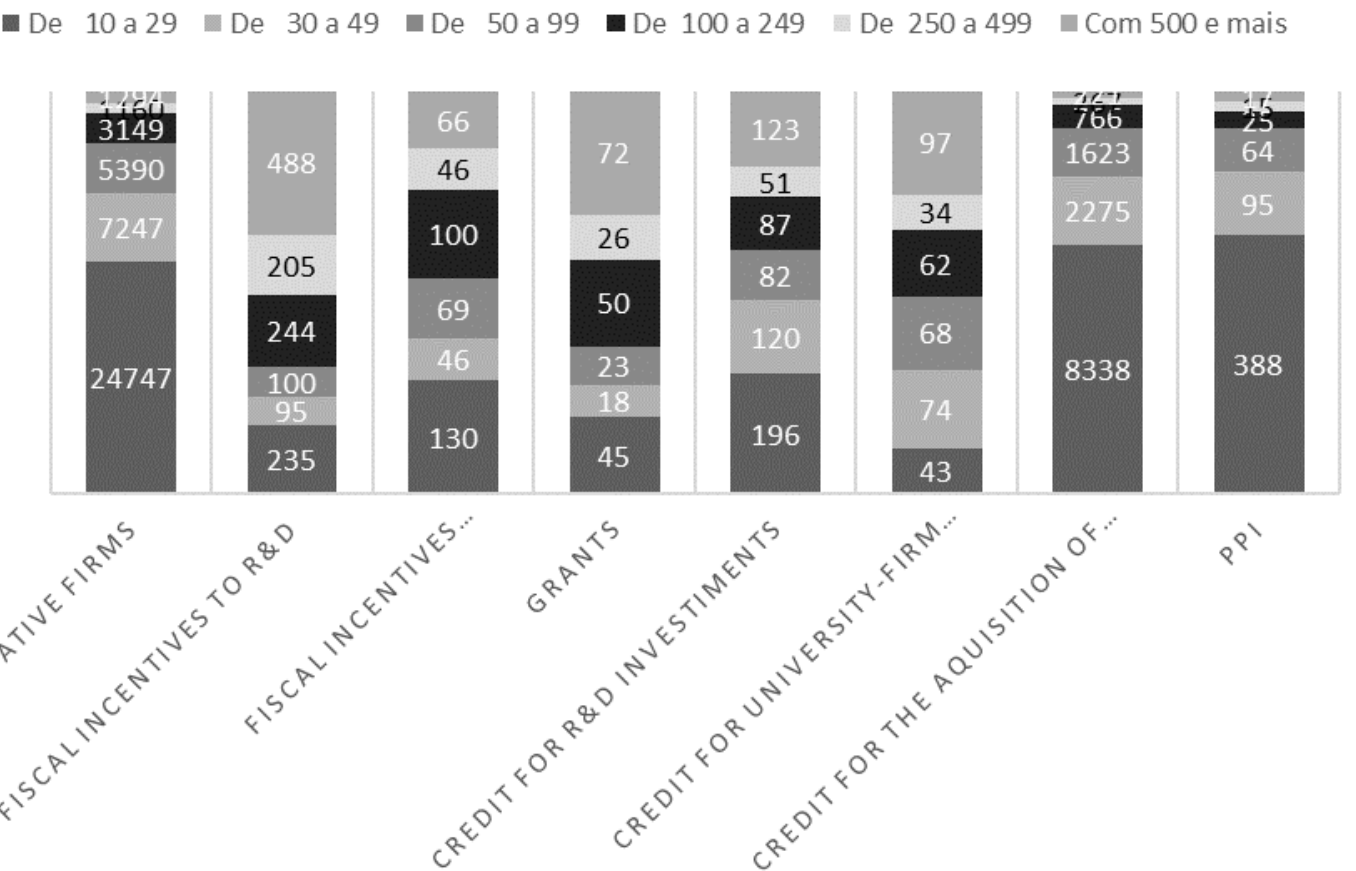

Source: IBGE, PINTEC (2014).

The results suggest an important role of PPI in incentivizing firms' innovative efforts, even when controlling for the presence of other policies. The analysis of this result should be accompanied by two other important perceptions. The first perception is that Brazilian innovation policy has had trouble in targeting small and medium size firms. An analysis of the policy instruments enrolled by PINTEC shows that large firms are more easily targeted by innovation policies instruments than large firms with the exceptions of the supply of subsidized credit for the acquisition of machinery and equipment and PPI (Figure 5). This perception is confirmed by other analyses, such as ABDI (2013:101) ${ }^{9}$ that states in its conclusions that innovation policy in Brazil has mostly targeted large firms, already innovative and high R\&D performers. Therefore, an innovation policy instrument able to overcome the obstacles to target smaller firms should be welcomed in the policy mix. This is even more important if one realizes that the acquisition of machinery has small effect on formal R\&D activities, in specific, and in other innovative efforts, more generally. In this sense, this policy may be viewed as complementary to credit for the acquisition of machinery. This is even more important when one understands that Brazil suffers of structural heterogeneity. High productivity firms appear in the same environments as very low productivity firms and one

\footnotetext{
${ }^{9}$ ABDI (2013) may be viewed as the most thorough governmental effort to assess innovation policy results. The document does not however cover procurement policy, neither the use of public funds to the acquisition of equipment and machinery with innovative purposes.
} 
Encontro Nacional de

Economia Industrial e Inovação
Indústria e Desenvolvimento Econômico:

desafios e perspectivas

18 a 20 de setembro de 2018

Uberlândia - Minas Gerais

main driver of this characteristic is the uneven diffusion of knowledge and innovation (Pinto 1970). Innovation policies should therefore account for this fault of the Brazilian production structure.

The second perception is a consequence of a systemic view of the innovative process. Policy should promote interaction between agents and procurement policies have this characteristic. It can foster information flows across firms and governmental enterprises and agencies. This is even more important when dealing with small firms. Rocha (2017) analyzing oil and gas suppliers to Petrobras was able to identify that the most important effect of PPI was to induce small firms to perform R\&D efforts. Furthermore, it supplied information on best practices and obliged firms to follow quality control programs. In the case of procurement of innovative goods, the exchange of information was crucial for a successful outcome. PPI supplies the tools for this type of interaction, most importantly for small firms that do not have access to international markets.

\section{CONCLUSIONS}

The aim of this paper was to assess the effect of PPI practices on firms private R\&D expenditures, holding the hypothesis that PPI has played a positive role in incentivizing firms to perform innovative efforts. PPI includes initiatives directly related to bringing about solutions not present in the market context before it takes place, the use of innovation-friendly practices to promote new the production of new goods and services, or the establishment of conditions conducive to firm capacitation and interactive learning.

The paper used data from the Brazilian Innovation Survey (PINTEC). PINTEC allowed the identification of those mining and manufacturing firms that were involved in PPI. We then built a control sample using coarsened exact matching and tested the effect of PPI on firms private $R \& D$ to sales ratio. The results show that firms increase their R\&D intensity between 3 and 6 percentage points, according to the controls used in the tobit model. Data also shows that most firms involved in PPI are small and belong to low technology sectors.

These features unshed an important characteristic of PPI that was previously emphasized by Rothwell (1984) among others: its ability to target small firms and contribute to local development. This should be said particularly important in a setting where there is the prevalence of high structural heterogeneity as is the case of Brazil. Thus, PPI may be an important tool to stimulate interaction between public and private sector and to overcome the uneven diffusion of technical progress.

The paper calls for further research on the subject as well. First, the method did not allow the adequate discrimination of the cases framed into law 12349, which is perceived as a turning point in governmental procurement in Brazil. Second, though we carry out a description of the targeted firms' size and sector, further analysis on policy targeting and selection mechanisms are still necessary to adequately assess PPI and its potential to promote local development and the improvement of firms' innovative conduct. Third, it is still necessary an examination of public capabilities to adequately promote innovation. In systems such as the Brazilian Health Process, the Defense Industry, Oil and Gas, Brazilian agencies and state-owned companies have learned and accumulated capabilities to foster innovation in the interaction with the 
Encontro Nacional de

Economia Industrial e Inovação
Indústria e Desenvolvimento Econômico:

desafios e perspectivas

18 a 20 de setembro de 2018

Uberlândia - Minas Gerais

public sector. However, in other sectors, this is not necessarily true and further studies are necessary to understand the real potential of PPI to widely promote innovation.

\section{REFERENCES}

ABDI. (2013). Mensuração e efetividade dos instrumentos de apoio à inovação no Brasil. Fonte: http://www.abdi.com.br/Estudo/Volume4.pdf.

Arrow, K. (1962). Economic Welfare and the Allocation of Resources for Invention. Em NBER, The Rate and Direction of Inventive Activity: Economic and Social Factors (pp. 609-626). Princeton: Princeton University Press. Fonte: http://www.nber.org/chapters/c2144

Block, F. (2008). Swimming against the current: The rise of a hidden developmental state in the United States. Politics and Society, 36(2), pp. 169-206. doi:10.1177/0032329208318731

Cassiolato, J. E., Lastres, H., \& Maciel, M. (2003). Systems of Innovation and Development Evidence from Brazil. Cheltenham: Edward Elgar.

Cunningham, P., Gök, A., \& Laredo, P. (2012). The Impact of Direct Support to R\&D and Innovation in Firms. Compendium of Evidence on the Effectiveness of Innovation Policy Intervention. Fonte: http://www.innovation-policy.org.uk/

de Sousa, R. A., \& Oliveira, J. M. (2010). Compras Governamentais: Análise de Aspectos da Demanda Pública por Equipamentos de Telecomunicações. Radar, 10. IPEA.

Edler, J., \& Georghiou, L. (2007). Public procurement and innovation-Resurrecting the demand side. Research Policy, 36, pp. 949-973. doi:10.1016/j.respol.2007.03.003

Edler, J., Georghiou, L., Blind, K., \& Uyarra, E. (2013). Evaluating the demand side: New challenges for evaluating. Research Evaluation, 21, pp. 33-47. doi:10. ló93/reseval/rvr002

Edquist, C., \& Zabala-Iturriagagoitia, J. M. (2012). Public Procurement for Innovation as mission-oriented innovation policy. Research Policy, 41, pp. 1757-1769. doi:10.1016/j.respol.2012.04.022

Edquist, C., Hommen, L., \& Tsipouri, L. (2000). Public Technology Procurement and Innovation. New York: Springer.

Edquist, C., Vonortas, N., \& Zabala-Iturriagagoitia, J. M. (2015). Introduction. Em C. Edquist, N. Vonortas, J. Zabala-Iturriagagoitia, \& J. Edler, Public Procurement for Innovation (pp. 134). Cheltenham: Edward Elgar.

Guerzoni, M., \& Raitieri, E. (2015). Demand-side vs.supply-side technology policies: Hidden treatment and new empirical evidence in the product mix. Research Policy, 44, pp. 726-747. doi:10.1016/j.respol.2014.10.009

lacus, S., King, G., \& Porro, G. (2012). Causal inference without balance checking: Coarsened exact matching. Political Analysis, 20(1), pp. 1-24. doi:10.1093/pan/mpr013 
Encontro Nacional de

Economia Industrial e Inovação
Indústria e Desenvolvimento Econômico:

desafios e perspectivas

18 a 20 de setembro de 2018

Uberlândia - Minas Gerais

King, G., \& Nielsen, R. (2016). Why Propensity Scores Should not Be Used for Matching. Fonte: https://gking.harvard.edu/publications/why-propensity-scores-should-not-be-usedformatching

Malerba, F., \& Nelson, R. (2011). "Learning and Catching Up in Different Sectoral Systems: Evidence from Six Industries. Industrial and Corporate Change, 20(6), pp. 1645-1675. doi:10.1093/icc/dtr062

Mazzucato, M. (2011). The Entrepreneurial State. London: Demos.

Pinto, A. (1970). Naturaleza e Implicaciones de la "Heterogeneidad Estructural" en America Latina. El Trimestre Económico, 37, pp. 83-100. Fonte: http://www.jstor.org/stable/20856116

Rauen, A. (2015). Compras públicas de P\&D no Brasil: o uso do artigo 20 da Lei da Inovação. Radar, 40. Brasília: IPEA.

Rauen, C. (2017). As Contratações de P\&D para a Nova Fonte de Luz Sincroton Brasileira. Radar, 52.

Fonte: http://www.ipea.gov.br/portal/index.php?option=com_content\&view=article\&id=306 01

Ribeiro, C. G. (11-14 de 52 de 2017). Encomendas Tecnológicas Realizadas pela FAB: O Programa KC-390. Radar. Brasília: IPEA. Fonte: http://www.ipea.gov.br/portal/index.php?option=com_content\&view=article\&id=306 01

Rocha, F. (2017). Procurement as innovation policy and its distinguishing effects on innovative efforts of the Brazilian oil and gas suppliers. Economics of Innovation and New Technology. doi:10.1080/10438599.2017.1408199

Rothwell. (1984). Technology-based small firms and regional innovation potential: the role of public procurement. Journal of Public Policy, 4(4), pp. 307-332. doi:10.1017/S0143814X00002774

Soares, R. P. (2005). Compras governamentais: características das firmas industriais e participação. Em J. A. DE NEGRI, \& M. S. SALERNO, Inovações, padrões tecnológicos e desempenho das empresas brasileiras (pp. 299-234.). Brasília: IPEA.

Squeff, F. d. (2014). O Poder de Compras Governamental como Instrumento de Desenvolvimento Tecnológico: O Caso Brasileiro. Textos para discussão do IPEA, 1922. IPEA.

Fonte:

http://www.ipea.gov.br/portal/index.php?option=com_content\&view=article\&id=211 16

Stuart, E. (2010). Matching Methods for Causal Inference: A Review and a Look Forward. Statistical Science, 25(1), pp. 1-21. doi:10.1214/09-STS313

Uyarra, E. (2012). Review of Measures in Support of Public Procurement of Innovation. Compendium of Evidence on the Effectiveness of Innovation. Fonte: http://www.innovation- 
Indústria e Desenvolvimento Econômico:

Encontro Nacional de desafios e perspectivas

18 a 20 de setembro de 2018

Economia Industrial e Inovação

Uberlândia - Minas Gerais

policy.org.uk/share/16_Review\%20of\%20Measures\%20in\%20Support\%20of\%20Public \%20Procurement\%20of\%20Innovation.pdf

Uyarra, E., \& Flanagan , K. (s.d.). Understanding the Innovation Impacts of Public Procurement. European Planning Studies, 18(1), pp. 123-143. doi:10.1080/09654310903343567 